\title{
MIR145 Pre-miRNA
}

National Cancer Institute

\section{Source}

National Cancer Institute. MIR145 Pre-miRNA. NCI Thesaurus. Code C82775.

MIR145 pre-miRNA is an oligoribonucleotide that is encoded by the human MIR145 gene and has a role in the regulation of gene expression. 